\title{
The Admission of New Students Based on Online System at SMAN 2 Singkawang
}

\author{
Sularto ${ }^{1)}$, Wahyudi ${ }^{2)}$, Sukmawati ${ }^{3)}$ \\ ${ }^{1)}$ Universitas Tanjungpura, Pontianak, Indonesia \\ E-mail: sulartototo75@gmail.com \\ ${ }^{2)}$ Universitas Tanjungpura, Pontianak, Indonesia \\ E-mail: wyudi_fkip@yahoo.com \\ ${ }^{3)}$ Universitas Tanjungpura, Pontianak, Indonesia \\ E-mail:sukmawati@fkip.untan.ac.id
}

\begin{abstract}
The application of online-based student admission aims to provide the widest possible opportunity for every citizen to obtain a fast, transparent and accountable registration service. The purpose of the research carried out at the State Senior High School 2 Singkawang (SMAN 2 Singkawang) was to describe the online-based prospective student admission planning at SMAN 2 Singkawang, organizing admissions based on online students at SMAN 2 Singkawang, the implementation of prospective participants online-based students at SMAN 2 Singkawang, online admission supervision of prospective students at SMAN 2 Singkawang, as well as an online evaluation of new student candidates at SMAN 2 Singkawang. The approach used in this study is qualitative research on the type of case study research. The results of the research that have been conducted include 1) Planning the recruitment process of online-based prospective students conducted by the agency and the school; 2) Organizing in the acceptance of new students through the division of committee work; 3) Implementation of new online-based student admissions is carried out in accordance with existing technical instructions; 4) Supervision carried out in new student admission activities is carried out by the principal as the head of the education unit and also as the person in charge of the activity; 5) On this online-based new student admission activity, it has run well. But there are those that are the main focus of supporting activities are the internet and electricity networks, so that these two facilities must be ensured in good condition.
\end{abstract}

Keywords: Admission of New Students; Online System

\section{INTRODUCTION}

One of the underlying components in quality education services is the education information management system provided to the community. Data accuracy, efficiency of time and speed of presentation of information data is one of the important factors in managing all forms of educational information. One form of activity in schools that can use an accurate, efficient and fast information system is the acceptance of new students.

The acceptance of new students is one of the school activity programs and is included in the planning of students in the scope of student management. Seeing the importance of the planning of these students, it is necessary to have a strategy that is good, planned, and measurable in order to produce the expected students. Planning students contain what strategies are used, the policies taken, what programs are implemented, what methods are used, the steps that must be carried out, how much the costs are calculated and setting standards that are considered as a form of success. Therefore planning must be done well because it will be a reference for the school in achieving its objectives in accordance with the school's vision and mission. The acceptance of new students is one of the most important management activities of students held by both public and private schools because the entry of new students to a school will have a positive impact on the school so that teaching and learning activities can continue optimally.

In accordance with Permendikbud No. 17 of 2017 concerning the acceptance of new students in kindergartens, elementary schools, junior high schools, senior high schools, vocational high schools, or other equivalent forms regulated about the mechanism for implementing the new student admissions, can be based online (in the network) or offline 
(outside the network). In implementing this online-based new student admission, the relevant education office has the authority as the implementing designer of new student admission activities and determines the prospective new students who are accepted in each school based on national values, additional value of the achievement certificates owned by new students and zoning of students' residences.

In this online-based new student admission process, it was only applied in three regions in West Kalimantan Province, namely Pontianak City, Singkawang City and Kubu Raya District which became piloting in the 2017/2018 school year. In the city of Singkawang, the implementation of new online-based student admission covers all state high schools, there are 10 schools in the state high school. The application of online-based student admissions aims to provide the widest possible opportunity for every citizen to obtain a fast, transparent and accountable registration service. The application of information technology system applications, on the one hand, provides advantages that can help in completing work. This shows that the computer is a very large information resource used for decision making. One of the senior high schools in Singkawang City that applies it is SMAN 2 Singkawang.

SMAN 2 Singkawang was established in 1983, located on Cimandiri Street, Pasiran Sub-District, West Singkawang District, which is geographically close to SMAN 10 Singkawang in Kuala Kelurahan, West Singkawang District and SMAN 9 Singkawang, South Singkawang District. The distance between SMAN 2 Singkawang and the two senior high schools is approximately $2 \mathrm{~km}$, this will have an impact on meeting the capacity of students when the zoning system is implemented. The zoning system policy is intended to bring the place of residence closer to the school. So with the distance factor zoning system, it is no longer an obstacle for junior high school graduates to continue their education in secondary education.

Based on the description of the condition data found, the researcher needs to conduct research focused on "The Admission of New Students Based on Online System at SMAN 2 Singkawang. The hope of this research can provide information related to the management process carried out from the planning, organizing, implementing, monitoring and evaluation stages that can be used in an effort to improve the quality of schools.

\section{RESEARCH METHOD}

The approach used in this research is a qualitative approach because this research intends to reveal holistically, deeply with its complexity. This research is a case, so the type of research used is a case study. Because of its profound nature, case studies generally produce a longitudinal picture, namely the results of data collection and data analysis within a certain period (Tika, 2005: 7).

\section{RESULT AND DISCUSSION}

\section{A. Result}

The researcher obtained several findings of research results related to the acceptance of new online-based learners from the process of planning, organizing, implementing, monitoring and evaluating.

The acceptance of new students is an annual routine activity carried out in each school. The planning process begins with the formation of a committee, a meeting of new student admission preparations which discusses the number of quota of students received in accordance with the number of available groups. Department of Education and Culture of West Kalimantan Province Department of Education and Culture of West Kalimantan Province through the Educational Technology Research and Development Unit (UPPTP) of the Education and Culture Office of West Kalimantan Province and PT. Telkom as a service provider (provider) conducts training on the process of receiving new students online based.

In the organizing process, there was found a complete committee structure from the person in charge, chairman, secretary, treasurer, and members including operators, file selectors, and registration officers. The acceptance of prospective new students is done online. There are 2 ways in registering new online-based students, the first way the prospective new students themselves register online through the provided web address, then prospective students verify the prospective student admission committee in the school to get proof of registration. The second way, students come directly to school, register, complete the file and the online registration is done by the committee. At the acceptance of prospective new students, the zoning system where prospective students live with school is applied. The size of the distance of residence to the destination school affects the additional zoning value points for prospective new students. There are three acceptance channels provided, namely regular/academic, achievement, and affirmation. Regular lines are purely the value of national exams used. The path of achievement is the value given to prospective students because the person in question has achievements in the academic and/or non-academic fields obtained at the junior high school level or equivalent. The path of affirmation is the value given to prospective orphaned students, neglected children who are cared for by the state, and underprivileged.

Supervision of the activities of prospective new students is carried out by the headmaster, from the provincial education and culture department there is no direct supervision of the school. The process of admission of prospective new students has been running according to the instructions, therefore the principal has assessed running smoothly, coordination among relevant institutions namely the Department of Education and Culture of West Kalimantan Province, Singkawang High School MKKS, PT. TELKOM, and PT. PLN has been well established so that when the process of receiving new students online is based there are no obstacles.

\section{B. Discussion}

Based on the findings of the study, researchers discussed and presented the results of research on the recruitment of new online-based prospective students ranging from planning, 
organizing, implementing, monitoring and evaluating. The data is obtained from interviews and documentation studies. The results of the research can be described as follows:

1. Recruitment Planning for Prospective Students Based Online

Planning is an activity to formulate a series of processes and ways that will be used to achieve a goal. In planning, there is also a thought of determining what will be done, how to do it, who is the executor, and when the activity must be carried out. Thus the recruitment planning of prospective students is a series of thoughts about the process of recruiting new students, from the formation of a committee, a committee meeting that discusses the amount of quota received, the techniques to be used, the requirements and time for the implementation of activities.

Based on interviews and documentation it was found that the recruitment planning of new students was in accordance with the planning process, which was preceded by the formation of a committee, a meeting that discussed the determination of the quota amount received, the method used was using the online system, the requirements imposed, and implementation time. This is in line with the opinion of Imron (2011: 21), student planning is an act of thinking ahead of things that must be done with regard to students in school, both since students will enter school and they will graduate from school. What is planned are things that must be done in relation to student admission up to the graduation of students. Opinions about the importance of planning were also put forward by Anderson and Bowman 1964 (in Sutisna 1989: 192), planning is the process of preparing a set of decisions for future actions. This definition suggests that planning leads to and includes making decisions. Decision making is often an important part of planning. It is a process in which a complete action program is prepared in advance before each part is carried out through specific decisions.

This is reinforced by Sagala (2002: 46) states that planning includes activities to determine what you want to achieve, how to achieve it, how long, how many people are needed, and how much it will cost. Thus the planning in new student admissions can go through several stages, including 1) the determination of the goals of new student admissions, 2) setting the level of targets for implementing new student admissions, 3) making technical guidelines and guidelines for new student admissions that contain the provisions general, new student admission requirements, registration procedures, determination of implementation schedule, registration fees, determination of capacity, student mutation, 4) facilities used in the process of receiving new students.

So by referring to the existing theory, it is stated that the planning process for the acceptance of prospective students has gone through the right stages or mechanisms. The planning stage has been taken in accordance with the technical guidelines issued by the education and culture department.
2. Organizing Recruitment of Candidates for Online-Based Students

Organizing is a systematic thinking about how work is organized in an organization by involving existing resources. Organizing is very important because an organization can move if there are resources that are driven to achieve organizational goals. According to Handoko 2003 (in Usman Husaini 2014: 170) organizing is (1) designing a formal structure for the most efficient use of financial, physical, raw material, and organizational workforce resources, (2) how the organization classifies its activities, where each grouping is followed by the assignment of a manager who is authorized to supervise group members, (3) the relationship between the functions, positions, duties of employees, (4) the way managers divide tasks that must be carried out in the department and delegate to do the tasks.

In this study, based on the results of interviews and documentation, it was found the formation of new student recruitment committees which in the committee structure had also divided the duties of each committee member. The technical delegation assignment was delivered at the committee meeting, namely, there were registration and information officers, data verification, data processing on the online system. Especially for data processing officers in an online system, people who really master computer applications are appointed so that they support data processing tasks in accordance with the existing technical instructions. This is consistent with the opinion of Usman Husaini (2014: 194) structure regarding work, while work influences the behavior of people in the organization. The organizational structure deals with the decision process in designing the organizational structure that involves (1) division of labor, (2) departmentalization, (3) range of control, and (4) delegation. This is reinforced by Latifah \& Fattah (2017: 75), arguing that an organizational structure specifies the division of labor and shows how the function or work activities and shows how different functions or activities are linked.

Based on the research findings, the organizational structure of the prospective new student admissions committee each function carries out its duties which in the process are interconnected with each other. Field descriptions of each element of the committee are very important to be elaborated and understood by each member of the committee because the respective job descriptions are interrelated with each other. This is in line with the thoughts of Latifah \& Fattah (2017: 75), namely the specialization of activities refers to the specifications of individual and group tasks throughout the organization or the division of labor and the integration of these tasks into work units. Furthermore, each member of the committee is given the authority to carry out their duties in accordance with their respective duties. This is in line with Latifah \& Fattah (2017: 77), authority is an institutional right to use power. Relations 
in this organization include responsibility as a person's obligation to perform its functions, as well as authority as an institutional right to use power, as well as reporting as an obligation to express results.

At the reception of prospective new student participants, the school has made the committee equipped with a description of the duties of each committee member. Description of important tasks because each personnel will know their respective workload in accordance with their main tasks and functions. In the job description, each committee member is given full authority to carry out their duties. The principal delegates and authorizes the authority to carry out the process of receiving new student candidates to the organizing committee. In this year's prospective student admission activities, there is a difference from the previous year, namely the implementation of an online system for data input. In this regard, special personnel is prepared who really understand and understand the use of computers and internet networks. The committee personnel who were prepared as online data processing operators were trained by the provincial education office in collaboration with service providers, namely PT Telkom.

The steps were taken by the school and the provincial education office in organizing the recruitment activities of prospective new students are in accordance with the existing theory in which committee assignments are given according to their specialization, for example, computer operator officers are appointed to those who understand and understand computers and networks Internet. The delegation and delegation of authority in carrying out committee work is fully entrusted by the principal to the organizing committee. The principal as the leader and person in charge of the activity is fully responsible for the process of receiving the new student candidates in the school he leads.

3. Implementation of Candidates for Online-Based Prospective Students

The implementation or actuating of new onlinebased student recruitment is an implementation of what has been made in the planning and organizing process. Actuating terms, there are some experts who call it the term 'directing'. This is in line with Terry's opinion (in Usman Husaini 2014: 172), directing is actuating is getting all members of the group to want to be directed to the objective of being willing with the managerial planning and organizing efforts. Therefore actuating is actually an action, because something will not happen if there is no action.

In connection with the above theory, then after planning and organizing, then proceed with the implementation of online-based new student recruitment activities carried out in accordance with the Decree of the Head of the Education and Culture Office No.796 of 2017 concerning Technical Guidelines for New Student Admission. The implementation of the PPDB registration process is based online, filling out the registration form, registration data entry, registration proof, PPDB online selection stage, SKHUN Value rating, residence zoning, achievement charter, inability certificate, announcement of selection results, re-registration.

In the 2017/2018 school year, the provincial education office appoints 3 district/city regions as pilots to carry out the acceptance of prospective new students online. The three regions are Pontianak City, Singkawang City, and Kubu Raya Regency. SMAN 2 Singkawang, one of the schools that organizes the acceptance of prospective students based on online.

In this implementation process, the stages of the prospective student admission process are running in accordance with the existing technical instructions. There are two registration models, first, the new prospective students come directly to school and both prospective students register online independently on the website https://kalbar.siap-ppdb.com then go to the destination school to get verification of proof of registration. There are three types of admission selection, namely general/academic selection with $60 \%$ quota, $15 \%$ achievement selection, and $25 \%$ affirmation selection. The zoning rules for residence to school are only applied to general selection, for achievement and affirmation selection do not use zoning systems. The existence of this zoning system that is not yet understood by the community, the purpose of zoning is the distance of the place of residence to the school, each of which has a range of points (according to the technical instructions). So the zoning point value will add to the point the final value of the acceptance of new students. Furthermore, after inputting the data, all prospective students will be ranked according to the selection path. For prospective students whose final grades are not included in the quota limit, they will be thrown to the second choice school and so on.

After the ranking results are in accordance with the quota, the school will announce the results of the acceptance of prospective new students, for prospective students who are declared accepted, are required to reregister according to the time specified. So thus in this implementation process in accordance with existing theories, organizational activities take place. The mobilization of all components of the resource takes place, under the control of the committee chairman as the field implementer and the principal as the person in charge of the activity.

4. Supervision of Online Recruitment of Prospective Students

Supervision is needed to see how far the process goes from planning, organizing and implementing to see the results achieved. According to Latifah \& Fattah (2017: 104), supervision is coercion or compelling which means that the process is force-compelling so that the implementation activities can be adjusted to the plan that has been set. Furthermore, it is also stated that the purpose of supervision is to help maintain results or output according to system requirements. 
In the process of receiving new online-based prospective students, the supervision process is carried out by the principal as the leader in the organization of the education unit and also the person in charge of the recruitment of prospective students based online. Supervision is carried out at each stage of the activity stages of registration, data verification, selection of data processing in the application system, announcement, and re-registration. This supervision is carried out at each stage with the aim that if there is a problem, coordination is immediately carried out so as not to impede the activity process. This is in line with the opinion of Soekarno (1982, in Torang 2016: 176), supervision is the control or control intended for; 1) knowing the suitability of the competencies possessed by someone with the tasks assigned to him, and 2) knowing the timeliness of the work with the results of the work, so that if the implementation of the inspection found errors or mistakes, immediate improvements were made so that the goals of the organization can be achieved effectively, efficiently and rationally.

Thus the supervision process is very important for the running of the organizational process. In accordance with the existing theory, in this supervision will be seen whether the human resources that have been appointed can carry out their main tasks and functions in accordance with the existing job descriptions. In this supervision process, when there is an error, repairs can be done immediately, so that the goals of the organization can be achieved.

5. Evaluation of Recruitment Candidates for Online-Based Students

Evaluation is an activity to see the achievement of each stage of the activity, if there are deficiencies, it can be a material for improvement notes. This is in line with the opinion of Eka Prihatin (2011: 164), evaluations are carried out during the program or activities take place and this is associated with the monitoring process. Furthermore, the information obtained through monitoring is made possible to be able to make and determine how the program can work or how it should be the process to achieve the objectives. The World Health Organization (WHO) also formulates evaluation as a process of collecting data analyzing information about the effectiveness and impact of a stage or the entire program. This evaluation also includes assessing the achievement of the program and detecting and solving problems and planning future activities.

Based on the findings that there are recruitment activities for prospective students based on this online, the evaluation process is carried out by the principal by looking at and evaluating the process as a whole. In this activity, the main concern that supports the course of activities is electricity and internet networks. Both of these are the main factors for the successful recruitment of prospective online-based students. Follow-up of this evaluation should always coordinate with parties related to service providers, in this case, PT. PLN and PT.
TELKOM, through recommendations from the Department of Education and Culture of West Kalimantan Province.

Thus, the evaluation process as a closing of the entire organizational process is very important. In the evaluation will collect all the data on the track record of the process of admission of prospective new students, which will then be analyzed throughout the process of activities, assess the process of activities, if there are problems can be a record for future improvements.

\section{CONCLUSIONS AND SUGGESTIONS}

\section{A. Conclusions}

Based on the results of the research and the discussion presented, it can be concluded as follows:

1. Planning the recruitment process of online-based prospective students is carried out by the agency and the school. The agency makes technical instructions for implementing new student admissions that refer to ministerial regulations. Especially for schools that implement new student admissions with an online system, the agency conducts training on the use of new online student-based admissions applications. The school in this planning formed a new student admission committee, including one of the committees participating in online-based application training for new students, determining the amount of quota received, making registration forms, facilitating supporting infrastructures such as rooms and furniture, checking internet networks, ensure a safe electricity network and announce to the public about the implementation time of new student admissions and the conditions required.

2. Organizing in the acceptance of new students with the division of committee work. Members of the committee in accordance with their ability are given the authority to carry out tasks, there are those in charge of registration and information, data verification, and data processing through online applications. Especially those who are assigned to the data processing section are appointed who have attended training and/or officers who are in control of the computer.

3. The implementation of new online-based student admissions is carried out in accordance with the existing technical instructions. Stages start from registration, form retrieval, filling in forms, submission of forms completed with the requirements required for data verification officers, processing data according to the form fill with existing academic paths, achievements or affirmations, ratification of proof of registration (as re-registration proof), announcement learners who are accepted, and reregister.

4. Supervision carried out in new student admission activities is carried out by the principal as the leader of the education unit and also as the person in charge of the activity. Supervision is carried out at each stage 
of the new student admission process to ensure there is no obstacle if there is a problem, coordination is immediately done to find a solution.

5. Evaluation is done to see which stages or parts still need improvement. In this online-based new student admission activity, it has run well. But there are those that are the main focus of supporting activities are the internet and electricity networks, so that these two facilities must be ensured in good condition.

\section{B. Suggestions}

Based on the description of the results of the research and the discussion above, the researcher presents the following suggestions:

1. To the agency, it should systematically supervise, because it is constrained by resources to monitor each school, it can be used to supervise by filling out questionnaires that can be used as a means of delivering opinions when things need improvement.

2. To the organizers of the school, the activity evaluation process must be formulated so that it can be a reference for improvement and subsequent follow-up.

\section{REFERENCES}

Imron, A. 2011. Manajemen Peserta Didik Berbasis Sekolah. Jakarta: Bumi Aksara.

Latifah, P., \& Fattah, N. (2017). Analisis Kebijakan Pendidikan. Bandung: Remaja Rosdakarya.

Permendikbud Nomor 17 Tahun 2017 tentang Penerimaan Peserta Didik Baru.

Prihatin, E. 2011. Teori Administrasi Pendidikan. Bandung: Alfabeta.

Sagala, S. 2002. Administrasi Pendidikan Kontemporer. Bandung: CV. Alfabeta.

Sutisna, O. 1989. Administrasi Pendidikan Dasar Teoritis dan Praktek Profesional. Bandung: Angkasa.

Tika, P. 2005. Metode Penelitian Geografi. Jakarta: Bumi Aksara.

Torang, S. 2016. Organisasi dan Manajemen. Bandung: Alfabeta.

Usman, H. 2014. Manajemen: Teori Praktek dan Riset Pendidikan. Edisi 4. Jakarta: Bumi Aksara. 